\title{
Network Model of Local Development Planning: Case of Local Development Planning Forum in Bone Regency
}

\author{
Nani Harlinda Nurdin ${ }^{1}$, Alwi $^{2}$ \\ ${ }^{1}$ Department Public Administration, Faculty Social and Political Sciences, Universitas Indonesia Timur (email: \\ naniharlinda@gmail.com), ${ }^{2}$ Department Public Administration, Faculty Social and Political Sciences, Universitas \\ Indonesia Timur (email: alwifisip@gmail.com)
}

\begin{abstract}
The complexity of development that occurs in development problems where stakeholders have difficulty in determining problems and finding solutions to these problems. This is due to the many actors involved with different needs and interests, so that the results of development are not of many benefits received by all levels of society. Musrenbang as a local development planning forum identified in this study as an network organization of local development planning, aims to encourage the involvement of stakeholders in designing local development planning programs. This study aims to develop a network model of local development planning in Bone Regency. The research uses a qualitative approach and consists of primary data and secondary data. The data collected is then processed throught data reduction. The results of the study show that the network model of local development planning has not been implemented, as can be seen from the absence of development programs oriented to the community, especially the poor. This shows the high level of poverty in Bone Regency.
\end{abstract}

\section{Keywords:}

network model; local development planning; Musrenbang

\section{Introduction}

Development is a process of developing community capacity in the long term so that it requires proper and accurate planning. Planning includes when, where and how the development is carried out in order to be able to stimulate sustainable economic and social growth.

In Act No. 25 of 2004 concerning the National Development Planning System states that planning is a process for determining appropriate future actions, through a sequence of choices taking into account available the resources. The resources in question are local potentials, abilities and conditions, including budgets to be managed and utilized for the

- Annual Conference, Bali, 11-12 November 2019 
welfare of the community. Whereas Law No. 23 of 2014 concerning Regional Government states that districts/cities are autonomous regions in the sense that regions have the authority to make policies to provide services, increase participation, initiatives and community empowerment aimed at empowering regions and improving people's welfare.

Development planning requires synergy between all actors and development actors to produce development that is in accordance with community needs. One of the forums used in the process of decision making and regional policy is the Regional Development Planning Conference called as the district/city Musrenbang. District/city Musrenbang is a strategic forum for development actors in formulating collaborative development planning involving 3 (three) pillars of government, namely local government (executive and legislative), private parties and the community.

The above mechanism needs to be a concern in the current implementation of regional development planning because development is in very complex conditions. The complexity of the development results in the development of uneven and not on target. So we need a concept approach so that decision making and policy can produce equitable and targeted development.

In the current study of public administration, one of the concepts used in decision making and policy implementation is through an inter-organizational network system. This concept appears along with changing times where the tendency in solving problems is no longer individually but involves other people and other organizations in solving internal problems in the organization. Experts who are concern in this regard state that the effectiveness of both public and private organizations is greatly determined by the network between organizations (Sydow 2002; Becerra; 1999).

At present, there is a tendency for organizations, both in private organizations and in public organizations, to solve complex problems through inter-organizational network systems. In this case, the network system between organizations is a collaboration the government, the government and the private sector/business organizations, and the government and NGOs. (Alwi \& Si, n.d.)

Based on the description above, the inter-organizational network system needs to be applied primarily to solve problems related to the welfare of the main community in terms of development. Impact of development in this country is in the form of positive and 
negative things that impact on society. One impact can be seen is that the rich get richer and the poor get worse.

One of the keys in the Musrenbang process is the deliberation in formulating regional policies and programs. The concept of "discussion" shows that the musrenbang forum is participatory and dialogical, not a seminar or information dissemination. So that the musrenbang process should not be arranged as a ceremonial event which is mostly filled with speeches and remarks. The essence of Musrenbang is the active participation of citizens. At each level of musrenbang, community engagement is a reflection of citizen participation as well as an arena of government accountability.

The musrenbang forum is the final step in the planning process, namely the examination of the document of the Initial Design of the Regional Government Work Plan of the district / city which is the result of the compilation of the Work Plan Design of the Regional Apparatus Organization which in this case is the result of a combination of the results of spatial and sectoral participatory processes (village Musrenbang, sub-district level up to local government communication forums) and technocratic process. However, even though the musrenbang is the final step in the discussion of documents that have been prepared through the previous tiered stage, government officials and various parties present should dialogically discuss the Initial Draft of the Regional Government Work Plan to agree on important matters related to their area.

The Musrenbang process in Bone district normatively has been carried out according to the mechanism, but there are still many problems that arise. Several regulations as indicators of development targets that have not yet been carried out as a result of not optimal coordination between sectors, limited time, limited human resources and budget constraints. The phenomenon that occurs in Bone district can be seen in the relatively high economic growth rate $(8.43 \%)$ and income per capita which can also be said to be quite high ((39.15 million), but the poverty rate remains high (77.13\%).

Based on this phenomenon, the existence of inter-organizational networks in the policy process has many benefits. As stated by Robert in Alwi (2012) that some stakeholders need an inter-organizational network approach to problem solving. Donaldson also explained that 90 percent of an organization's performance is determined by external factors and only 10 percent is determined by internal factors (Alwi, 2012: 95). From his opinion 
Donaldson shows that inter-organizational relations are an important concern in the performance of an organization.

Research related to network studies has been conducted previously by Alwi (2012) Network Implementation Analysis on Democratic Public Service, which examines the network analysis of policy implementation in democratic public services in Makassar City. The results showed that the implementation of inter-organizational network (city transportation) public services was not effective. Another network-related study was also conducted by Gita Susanti (2012). From the results of his research found that the information system and coordination is not optimal by the Makassar city education council, so that it has an impact on the success of establishing democratic network-based educational services.

The difference between this research and the previous research is looking at and analyzing the implementation of Musrenbang in terms of the interrelationship between organizations and actors involved in the formulation of development activities in Bone district using institutional theory. Institutional theory focuses on the importance of values and norms in an organization to obtain the needed resources. In general, this theory tries to explain that organizations in their efforts to achieve goals need to get acceptable acceptance and legitimacy from the environment in which the organization is located.

\section{Network Perspective}

Lately, the concept of Network has become a concept that is widely discussed by various parties, both by the government, scientists (social and nature), business practitioners, and by the community in general. In political science, the word "network" is often used by both politicians and academics to explain the importance of the presence of stakeholders from various backgrounds in discussing and deciding on a political decision that we know as the public policy.

The development of network concepts that occur in various scientific disciplines confirms that the concept or approach to the network (network approach) is indeed a study that needs serious attention as a result of the growing complexity in the present conditions. The same thing was also confirmed by Kenis and Schneider (1991) as follows: "The term network seems to have become the new paradigm for the architecture of complexity". 
Network theorists see a normative approach focusing on culture and the process of socialization that instills (internationalization) norms and values in actors. This normative approach explains that what unites people together is a set of shared ideas. Network theorists reject this view and claim that one must focus on the pattern of objective bonds that connect community members (Mizruchi, 1994 in Ritzer and Goodman, 2004)

Network theory focuses both on microstructure to macro. This view means that in network theory, actors can be individuals, groups, companies, and society. Relationships can occur at all levels, both at the broad and small scale social structure level. Granoveter (1985) describes relationships that occur at the micro level such as actions that are "attached" to concrete personal relationships and within the structure (network) of those relationships. This relation is based on the idea that each actor (individual or collective) has different access to valuable resources (wealth, power, and information) so that the structured system tends to be stratified, certain components depend on other components.

There are various thoughts in network theory, but Wellman in (Ritzer and Goodman 2004) mentions principles that are logically related to describing network theory, among others: 1) Bonds between actors are usually systematic in both their level and intensity. Actors exchange with something different and they do it with an intensity that can get bigger or smaller; 2) Bonds in individuals must be analyzed in the context of a broader network structure; 3) Structured social ties give rise to various types of regular networks. On the one hand, the network is transitive. If there is a bond between A and B and C, then there is likely a bond between A and C; 4) The existence of a network group causes the creation of cross relations both between network groups and between individuals. 5) Asymmetric ties between elements in a network system with the result that limited resources will be distributed unevenly; 6) Unequal distribution of limited resources causes cooperation and competition. Some groups will join to get limited resources by working together, while other groups compete and fight over it.

The above principle asserts that the network is formed based on the logical consequences of human tendency to think rationally so that when they are confronted with certain conditions that require them to use factors outside themselves, it creates an embryo of cooperation which is the basis of developing the concept of the network. 


\section{Inter-Organizational Network}

The use of the concept of inter-organizational network as a strategy in managing public sector management indicates that the network approach is a tool that must be developed and implemented in managing various public agendas. In the Alberta Heritage Foundation for Medical Research (2003), defining networks as: “Networks are valuable tools that can be used to contribute to the accomplishment of a wide range of objectives, and there are specific contexts where network activity is particularly well suited".

It can be seen that the focus of the network concept focuses on managing diverse objectives so that when the problem is complex, the network approach is a tool that should be considered both in determining policy formation and implementation (policy execution). The network perspective has several theories that are used as approaches to understanding network phenomena from different perspectives from one another.

Associated with a network perspective, Cho, et al (2005) in Purwanto and Sulistyastuti (2012: 146-147) state that there are several activities that accompany interorganizational networks in the implementation process. First: even though there is a hierarchy, it does not mean that the relationships between organizations in the structure are merely hierarchical relationships. Second: the inter-organizational approach, also emphasizes it (network) the implementation process. Above it has been explained that the theory used in analyzing the musrenbang process in Bone district in a network perspective is institutional theory.

\section{Institutional Theory}

This perspective initially departs from sociological concepts that explain the dynamics that occur in an organization consisting of a group of people. Paul J. Di Maggio and Walter W. Powell (1983) state that institutional theory arises over criticism of economic theory and contingency which only explains organizational structure with efficient measures, tends to be very rational and ignores the external factors of organizations that have power and are non -rational like the State, norms, traditions and conventions that are actually also very influential in the process of forming these organizations.

Old institutionalism focused on formal political institutions and constitutions defined in terms of parliament, government and the legal system (see Finer 1954; Duverger 
1959; Johnson 1973), while new institutionalism had a broader scope, institutional focus that included not only institutions formal politics, but also less formal institutionalization of interaction patterns between different political actors (Rhodes 1995: 54; Peters 1999: 18).

In general, this theory tries to explain that organizations in their efforts to achieve goals need to get acceptable acceptance and legitimacy from the environment in which the organization is located. To improve organizational competitiveness, the foundation of organizational normative values such as effectiveness, efficiency, and economics in achieving organizational goals must be a serious concern for organizations to be able to survive in the current era of globalization. Scott (2001) defines the institution as. : "Institutions consist of cognitive, normative, and regulative structures and activities that provide stability and meaning to social behavior. Institutions are transported by various carriers, cultures, structures, and routines and the operation at multiple levels of jurisdiction".

By referring to the definition of Scott (2001), there are three main pillars of this theory which are the foundation of an organization in the formation of its legitimacy, namely the cognitive cultural pillar, the normative pillar, and the regulative pillar. Cognitive pillars include symbols, beliefs, and social identities that involve shared conceptions and frames that focus on understanding meaning. Normative pillars include obligations, norms, and social values that contain evaluative dimensions. While the regulative pillar is a pillar that contains rules, laws, and sanctions.

Picture 1.

Three Pillars of Institutions

\begin{tabular}{|c|c|c|c|}
\hline $\begin{array}{c}\text { Basic of } \\
\text { compliance }\end{array}$ & Regulative & Normative & Cultural-Cognitive \\
\cline { 2 - 4 } & Expedience & Social obligation & $\begin{array}{c}\text { Taken for grantedness } \\
\text { shared understanding }\end{array}$ \\
\hline Basic of order & Regulative rules & Binding expectations & Constitutive schema \\
\hline Mechanisms & Coercive & Normative & Mimetic \\
\hline Logic & Instrumentality & Appropriateness & Orthodoxy \\
\hline Indicators & Rules, laws, sanctions & $\begin{array}{c}\text { Certification, } \\
\text { accreditation }\end{array}$ & $\begin{array}{c}\text { Common beliefs, } \\
\text { shared logics of action }\end{array}$ \\
\hline $\begin{array}{c}\text { Basic of } \\
\text { legitimacy }\end{array}$ & Legally sanctioned & Morally governed & $\begin{array}{c}\text { Cultural supported, } \\
\text { conceptually correct }\end{array}$ \\
\hline
\end{tabular}

Source: W. Richard Scott, Institutions and Organitazations (2001)

Institutional theory is generally used to understand social structures, including rules, norms, routines that serve as guidelines for social behavior in a particular community or 
organizational context. Furthermore, this theory gets a very good reputation in explaining individual and organizational actions (Dacin at all, 2002). The basis of this argument was sparked by WR Scott (2013) along with his activities studying processes in various organizations, where he found that work arrangements (work / organizational arrangements) were not based on a set of economic laws (natural economic law), but were shaped by political, social processes and cultural. This process is then known as institutionalization, where both individual and collective activities in an organization are limited and facilitated by institutionalized norms, rules, habits, culture and beliefs. Thus, institutional theory focuses not only on the organizational structure, but rather on the actors and their actions.

Scott (2013) defines the concept of an institution as "comprise regulative, normative and cultural-cognitive elements that, together with associated activities and resources, provide stability and meaning to social life". From here, Scott emphasized his framework in institutions, focusing on three institutional pillars namely, normative, regulative and cultural-cognitive. Institutions, in other words can also be interpreted as a strong social structure formed by symbols, social activities and material resources (ibid).

\section{Methods}

This study uses a qualitative approach with the consideration that the problems that emerge as a result of musrenbang are network-based policies that emphasize more on processes (Yin, 2000). The decision making process (decision making process) in regional development becomes an important study for all parties / actors involved in the process who incidentally have different background interests. The data obtained is based on observations and events that occur at the study site in accordance with the focus of the study. While other data sources were obtained through documents relating to the focus of the study. While the data collection techniques used are interviews, observation and documentation.

Data analysis techniques using the model of Miles \& Huberman in Sugiyono (2014), which suggests that the activities in qualitative data analysis are carried out interactively and continue continuously until completion, so that the data is already saturated. There are three activities in data analysis, namely: data reduction, data display, and conclusion drawing/verification. 


\section{Results and Discussion}

The dimensions of institutional theory (Scott, 2001) are cognitive pillars, normative pillars and regulative pillars. The three elements are considered by theorists as vital elements of the institution. Because Musrenbang is an institution in formulating development policies, the writer tries to analyze the musrenbang process in Bone district using institutional theory with a focus on 3 (three) elements related to existing phenomena. So it can be seen whether the values and systems that should be implemented in the musrenbang process are in accordance with the dimensions referred to in this theory. Cognitive regulative, normative and cultural-cognitive elements are indeed the focus of attention in institutional theory (Scott, 2013), but we cannot separate them from other processes that also play a role in the institutionalization process. The following are the results of research related to the three dimensions:

\section{Regulative Pillar}

The regulatory pillar is the first element in institutional theory, where it functions to regulate and limit behavior. This is done through a regulative process related to the capacity of institutions to make rules, ensure that all members adhere to these rules, and manipulate sanctions, rewards, and penalties aimed at influencing behavior (Scott, 2013).

In Bone regency the regulation governing the Musrenbang mechanism is a Regional Regulation (Perda) of Bone Regency Number 08 of 2008 concerning Musrenbang. The Regional Regulation clearly states that the principles that must be implemented in the musrenbang are empowerment, openness, accountability, sustainability, participation, efficiency and aspirations. Likewise with the objectives of the Musrenbang, among others, is to improve the quality of development planning determined based on a study of the problems of various fields of development by finding, analyzing and determining programs and activities that are in accordance with the aspirations and needs of the community as material in the preparation of the Regional Budget.

The results of the study show that although there are regulations that regulate the mechanism, it is only used as a formal matter and seems to be a formal forum as an activity that is only an abortion. The Musrenbang was attended by various government agencies, 
companies, non-governmental organizations (NGOs) and the general public. But their presence does not fully represent the needs of the community but only to meet their needs, because those present are actors who are close to the government. This is due to the absence of force or regulation which is coercive in imposing sanctions according to their level if there are items in the regulation that do not work.

In relation to this pillar, regulations are needed that regulate the rights of the actors, especially in involving the community. Likewise with the sanctions applied so that the objectives of the Musrenbang institutions are more optimal in producing development policy formulations.

\section{Normative Pilar}

Normative pillars are institutional elements that emphasize normative rules that introduce perspective, evaluative dimensions and obligations in social life. This normative system consists of values and norms, where values are interpreted as preferred or desired conceptions along with standard constructs where existing behavior or structure can be compared and assessed. While the norm functions to guide how something should be done/done. Thus, it can also be said that the normative system in the institutionalization process does not only talk about goals, but also focus on how to achieve these goals or methods.

Normatively the results of the formulation in the musrenbang are outlined in the Local Government Work Plan document as a reference in carrying out its activities and determining its budget. The results showed that there were still some problems in development as illustrated in table 1:

Table 1.

Problems in Development in Bone District

\begin{tabular}{cll}
\hline No & \multicolumn{1}{c}{ Aspect } & \multicolumn{1}{c}{ Problem } \\
\hline $1 \quad$ Education and Health & $\begin{array}{l}\text { There are still areas that have not } \\
\text { been reached by education and lack } \\
\text { of health facilities and specialist } \\
\text { doctors. } \\
\text { The ability of funding is not } \\
\text { comparable with the demand for } \\
\text { road rehabilitation from the } \\
\text { community and the lack of road } \\
\text { facilities in a number of economic }\end{array}$ \\
\hline
\end{tabular}


centers

3 Public Housing and Settlement Areas

4 Peace, Public Order and Community Protection

5 Social

6 Labor

7 Women's empowerment and protection

8 Food

9 Land

10 Living environment

11 Population administration and registration

12 Community and village empowerment

13 Population and family planning control

14 Transportation, communication informatics

15 Investment, Cooperatives, Small and Medium Enterprises

16 Youth and Sports

17 Culture and Tourism

18 Marine and fisheries
There is no coordination between Regional Apparatus Organizations and between levels of government in handling problems in residential and residential areas, such as handling rubbish, drainage channels, floods, etc. And there are still uninhabitable houses.

Enforcement of local regulations governing security and order issues in the community is still not optimal Lack of Social Services Facilities and Infrastructure and the lack of role of social institutions in handling social welfare issues

The unemployment rate is still conceited.

child Cases of domestic violence are still

high and community understanding of child protection is still low.

That is no government rice barn yet.

Certified land is still lacking

Adherence to Environmental Permits is still low.

civil Inadequate population services and infrastructure and inadequate sanctions for non-compliance with population documents Coordination on program implementation from the center to the regions is not optimal Lack of information and education about reproductive health.

and Limited resources and not yet optimal function and performance of transportation facilities and infrastructure

d Investment climate has not yet developed and investment realization has not met the expected.

community participation in youth and sports services has not been optimal

Facilities and infrastructure are not yet supportive

The high number of poor people on the coast 


\begin{tabular}{|c|c|c|}
\hline 19 & Agriculture & $\begin{array}{l}\text { Limited access of farmers in } \\
\text { technology and market information. }\end{array}$ \\
\hline 20 & Trade and industry & $\begin{array}{l}\text { Lack of capital and supporting } \\
\text { infrastructure }\end{array}$ \\
\hline 21 & Supervision & $\begin{array}{l}\text { Has not fully met the criteria for } \\
\text { Good Governance and Clean } \\
\text { Government. }\end{array}$ \\
\hline 22 & $\begin{array}{l}\text { Regional Autonomy, General Government, } \\
\text { Regional Apparatuses, and Staffing. }\end{array}$ & $\begin{array}{l}\text { The lack of optimal apparatus } \\
\text { empowerment in each work unit. }\end{array}$ \\
\hline 23 & Regional Revenue & $\begin{array}{l}\text { System and procedure for collecting } \\
\text { local revenue services is not yet } \\
\text { perfect. }\end{array}$ \\
\hline 24 & Regional Finance and Assets & $\begin{array}{l}\text { Limited infrastructure of integrated } \\
\text { financial management systems }\end{array}$ \\
\hline
\end{tabular}

Source: Report of Bone Regency Local Government Work Plan 2019

Table 1 illustrates that the overall development target indicators have not been achieved optimally. If it is related to the normative dimension in this study, after the formulation of the activity plan is included in the document as a reference, whether it is in the form of a Regent Regulation should be followed by Standard Operating Procedure (SOP) in each indicator of the development target. It is intended that there are boundary guidelines that must be followed by the actors. Not only that, this system is in addition to limiting, functioning to facilitate, encourage and empower the activities of actors, by placing norms as an explanation of the obligations that actors must carry out in accordance with the mandate or role given (Scott, 2008). For example, certain roles can give an individual certain access to material resources to carry out those roles. Roles in an organization can be formed formally, where these roles have specific goals and activities by individuals who are given or have certain positions in social contexts. But in other contexts, the role can also arise in individuals informally through ongoing interactions.

\section{Cultural Cognitive Pillar}

Cultural-cognitive pillar is a shared conception that describes the characteristics of social reality and provides a frame where meanings in a community or social life are produced and reproduced (Scott, 2014). This element represents and describes a culture/knowledge system such as shared beliefs/beliefs in a community, and the relationship of shared beliefs with cognitive patterns in thinking, feeling and acting (Hofstede et al 1991, Scott 2012). Thus, cognitive culture in the context of institutionalization 
is a process of sedimentation and crystallization of meaning in an objective form through a process of internal interpretation formed by an external cultural framework.

The results showed that all stakeholders agreed that if the planning was done well, the results in the form of automatic development would be good. There must be actions together. However, if seen the problems in table 1 illustrate that in carrying out the activities, each regional device organization carries out according to the interests of the organization. This is due to the absence of an agreed reference in carrying out actions or activities based on what has been planned and determined. This is where collaboration is needed between organizations or actors in carrying out what has been agreed and shared together.

\section{Conclusion}

Various things are needed in building networks with institutions or organizations. Noteworthy in this case include: compatibility, capability, and commitment. The main requirement in building cooperation in organizations is compatibility. It can be said that cooperation can be carried out if there is a match such as in the vision and mission and programs related to regional development. In a network system, the ability of organizations to build cooperation with other organizations that will become partners or between actors in other organizations is important. Commitment is one of the important things in building networks between organizations within an institutional framework so that what has been agreed can be carried out together as well. System and values and norms as a common reference are important if they are related to the three institutional dimensions. This is certainly very supportive of the implementation of programs that will ultimately realize the development goals as planned more optimally.

\section{References}

\section{Books}

Alwi, 2019. Kolaborasi dan kinerja kebijakan (Tantangan dan strategi dalam penentuan dan implementasi kebijakan): Kedai buku Jenny. Yogyakarta.

Lester and Stewart. 2000. Public Policy An Rvolutionary Approach, (second edition). Wadsworth Thomson Learning : USA 
Klijin, E.H. \& Joop Koppenjan. 2016. Governance Networks in the public sector. Routledge. New York

O'Toole,L.J.Jr. 2012. Interorganizational Relations in Impelemntation. In Peters, B,G and Pierre,J. Handbook of Public Administration (Second Edition). Sage Publication:London.

Sydow, Jörg, (2002), Inter-organizational Relations, Dalam Sorge, Arndt. (Editor). 2002., Organization, London, ThompsonLearning.

Powers, Jennifer Goodall, (2001). The Formation of Interorganizational Relationships and the Development of Trust. (Dissertation) Melalui http://www.pogodesigns.com/jp/ jpowers.pdf

Creswell, W, John. 2014. Penelitian Kualitatif dan Desain Riset, Memilih Diantara Lima Pendekatan. (edisi terjemahan). Pustaka Pelajar: Yogyakarta.

Dunn, N, William. 2003. Pengantar Analisis Kebijakan Publik. Edisi Kedua (Edisi Terjemahan). Gadjah Mada University Press: Yogyakarta.

Dye, T, R. 2008. Understanding Public Policy, Eleventh Edition. Prentice Hall. Islamy, Irfan. 2009. Prinsip-prinsip Perumusan Kebijaksanaan Negara. Bumi Aksara: Jakarta.

W. Richard Scott, 2001, Institutional and Organizations, SAGE Publications

\section{Journal article}

Alwi, D., \& Si, M. (n.d.). MELALUI SISTEM JARINGAN ANTAR ORGANISASI Oleh: Abstract. 218-231.

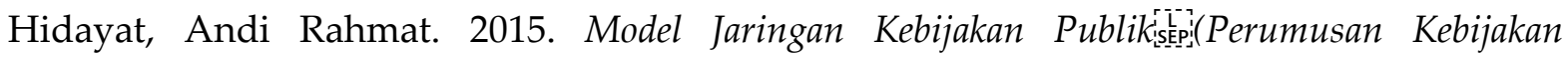
Masyarakat Adat Ammatoa Kajang Di Kabupaten Bulukumba) . JAKPP. Vol.1 Hal 209-219

Susanti, Gita, 2012. Jaringan Pelayanan Publik Yang Demokratis Dengan Studi Kasus Penentuan Strategi Pelayanan Pendidikan Berbasis Jaringan Di Kota Makassar. Disertasi. Universitas Hasanuddin:Makassar

Hill, Carey, (2002), Network Literature Review: Conceptualizing and Evaluating Networks. Melalui http://www.sacyhn.media/pdf/literatureReview.pdf

Nanang Haryono.2012. Jejaring Untuk Membangun Kolaborasi Sektor Publik. Jejaring Administrasi Publik. Th IV. Nomor 1, Januari-Juni. 